\title{
Flowering conditions affect flower longevity in Syringa vulgaris and cause changes in protein content, protease activity and expression of a KDEL-CysEP gene
}

\author{
Agata Jędrzejuk $^{1}$ Julita Rabiza-Świder ${ }^{1} \cdot$ Ewa Skutnik $^{1} \cdot$ Margrethe Serek $^{2}$
}

Received: 30 April 2015/Revised: 4 December 2015/ Accepted: 9 December 2015/Published online: 25 January 2016

(C) The Author(s) 2016. This article is published with open access at Springerlink.com

\begin{abstract}
Forcing is a method that is usually used to induce flowering in plants, independent of the natural blooming period. The temperatures required to start blooming in lilac in November are ca. $37^{\circ} \mathrm{C}$ causing degeneration of flowers. Forcing at $15{ }^{\circ} \mathrm{C}$ in November requires 49 days to bloom as compared to 23 days for the standard $37^{\circ} \mathrm{C}$, but gives panicles of much better quality than those forced by standard method $\left(37^{\circ} \mathrm{C}\right)$. In this study, we have investigated the protein content, total protease activity, and cysteine protease activity at different stages of flowering (flower bud whitening and swelling, open flowers, wilted flowers) for lilac flowers (Syringa vulgaris L., fam. Oleaceae) blooming under three different conditions: natural conditions in May and forcing in a greenhouse in November at $37{ }^{\circ} \mathrm{C}$ (standard forcing) or at $15{ }^{\circ} \mathrm{C}$ (alternative forcing). The protein content was relatively constant during flowering for each of the three sets of conditions. Flowers from $15{ }^{\circ} \mathrm{C}$ had a significantly lower total protease and cysteine endoprotease activity than flowers from $37^{\circ} \mathrm{C}$ at all stages. Flowers from plants blooming in May had a very time-specific cysteine protease activity, which was dramatically higher for the open flower stage than for the other stages. The partial coding sequence
\end{abstract}

Communicated by Z.-L. Zhang.

Agata Jędrzejuk

agata_jedrzejuk@sggw.pl

1 Department of Ornamental Plants, Faculty of Horticulture, Biotechnology and Landscape Architecture, Warsaw University of Life Sciences, Nowoursynowska 166, 02-787 Warsaw, Poland

2 Institute of Horticulture Production Systems, Floriculture, Leibniz University Hannover, Herrenhäuser Str. 2, 30-419 Hannover, Germany for a KDEL-CysEP was isolated, and its expression was determined by qRT-PCR. The gene expression did not correlate with the cysteine endoprotease activity especially in May natural flowering and November alternative forcing at $15{ }^{\circ} \mathrm{C}$. Alternative forcing method at $15{ }^{\circ} \mathrm{C}$ affected the flowering process delaying senescence, presumably due to the low cysteine protease activity.

Keywords Flowering · Forcing - Programmed cell death · Senescence

\section{Introduction}

Common lilac (Syringa vulgaris L. fam. Oleaceae) is a popular ornamental shrub. Under natural conditions of the temperate zone its flowering usually starts in May. Its flowering period is relatively short—it lasts ca. 3 weeks. Properly applied forcing procedures induce lilac flowering at any time between November and May, filling in the market niche when the supply of naturally flowering plants is small.

Overcoming flowering frequency and prolonging it beyond the natural dates, was always a challenge to plant scientists as well as for growers (Dale et al. 1999). Forcing is a method used to induce plant vegetation and blooming apart of the natural time in many bulbous, shrubs, and trees. The temperatures required to begin the forcing cycle of lilac ranges from $37{ }^{\circ} \mathrm{C}$ in November to $16{ }^{\circ} \mathrm{C}$ in March. Jędrzejuk (2005) and Jedrzejuk and Lukaszewska (2008a, b) have shown that in lilac, the high temperatures applied in November cause degeneration of pollen grains and ovules. This does not occur in flowers forced in March or blooming under natural conditions in May. Studies on the relationship between temperature and the length of lilac 
forcing cycle has shown that forcing at $15^{\circ} \mathrm{C}$ in November is also effective, but requires 49 days as compared to 23 days for the standard $37^{\circ} \mathrm{C}$ used by growers. However, panicles produced at $15{ }^{\circ} \mathrm{C}$ were completely filled with flowers while panicles produced by the standard high temperature treatment tended to be floppy and with flowers that were not completely open (Jedrzejuk and Lukaszewska $2008 \mathrm{a}, \mathrm{b}, \mathrm{c})$. Senescence is the last developmental stage occurred in many plant organs, including leaves, flowers, and fruit. It may be caused by organ age, biotic or abiotic stress, day shortening or application of plant hormones (Ellis et al. 1991). Programmed cell death (PCD) in plants, is a part of senescence process, as well as a normal part of life cycle (Steller 1995). Main research-based on model plants shown that PCD in flowers starts early, e.g., in flower bud (Panavas and Bubinstein 1998; Wagstaff et al. 2003; van Doorn et al. 2003; Battelli et al. 2011; van Doorn and Woltering 2008). Petal degradation is mostly observed at the ultrastructural level, but in Alstroemeria, Iris, Sandersonia or Hemerocallis (Wagstaff et al. 2003; van Doorn et al. 2003; Eason et al. 2002; Stead and van Doorn 1994), mesophyll degradation could also be visible under the light microscope. In common lilac, the first symptoms of cell degradation in flowers, such as degradation of nuclei and mitochondria, breakdown of cell walls, and cytoplasmic digestion, appeared earlier in flowers forced in November under high temperatures than in flowers blooming naturally in May (Jędrzejuk et al. 2013).

Proteolytic activity is one of the most important processes in PCD (Bieleski 1995; Brzin and Kidric 1996; Soudry et al. 2005; Azeez et al. 2007). During proteolytic activity proteases are released from vacuoles into the cytoplasm. Cysteine proteases (CysPs) are key enzymes involved in the senescence of flowers and leaves (Jones et al. 2005 according to Jones et al. 1995; Valpuesta et al. 1995; Wagstaff et al. 2002; Coupe et al. 2003; Eason et al. 2002, Azeez et al. 2007). The goal of current research was to investigate the protein content, total protease activity, and cysteine endoprotease activity in common lilac flowers (S. vulgaris L., fam. Oleaceae) blooming under three different conditions: natural conditions in May and forcing in a greenhouse in November at $37{ }^{\circ} \mathrm{C}$ (standard forcing) or at $15^{\circ} \mathrm{C}$ (alternative forcing). The protein content was relatively constant during flowering for each of the three sets of conditions. Flowers from shrubs blooming in November at $15{ }^{\circ} \mathrm{C}$ had a significantly lower total protease and cysteine endoprotease activity than flowers from shrubs blooming in November at $37{ }^{\circ} \mathrm{C}$ at all stages. Cysteine endoprotease activity in flowers collected from shrubs blooming naturally in May was the highest at the open flower stage. Plant cells undergoing cell death express a specific group of cysteine endopeptidases containing a C-terminal KDEL tail (Hierl et al. 2012). In petals, several cysteine protease genes are distinguished, and mostly their expression increases, when the senescence starts (Battelli et al. 2014). In current study, we isolated the partial coding sequence for a KDEL-cysEP to determine its expression in different developmental phases and three different blooming conditions, by qRT-PCR. The gene expression did not correlate with the cysteine endoprotease activity especially in May natural flowering and November alternative forcing at $15^{\circ} \mathrm{C}$. November alternative forcing method at $15^{\circ} \mathrm{C}$ affected the flowering process resulting in the low cysteine endoprotease activity and delaying the senescence.

\section{Materials and methods}

\section{Plant material}

Petals were isolated from flower buds and flowers of common lilac cv. 'Mme Florent Stepman' (shrubs flowering naturally in the field in May and from those forced in the greenhouse in November). Forcing was done either by the standard method at $37^{\circ} \mathrm{C}$ or by the alternative lowtemperature method at $15^{\circ} \mathrm{C}$. All experiments were replicated twice in the years 2012-2013. The plant material was sampled at the following developmental phases as described by Jędrzejuk et al. (2013) (Fig. 1): (A) inflorescence bud swelling, (B) inflorescence elongation, (C) flower bud whitening, (D) flower bud swelling, (E) open flower, (F) flowers completely wilted. To assure homogeneity of the sampled material all samples were collected from the lowest branches of the inflorescence. Four different phases of flower development and senescence (developmental phases C-F) from three different treatments (natural growth in the field, November standard forcing under $37{ }^{\circ} \mathrm{C}$, November alternative forcing under $15^{\circ} \mathrm{C}$ ), were used for all analyses.

\section{Soluble protein content, total proteolytic activity, and total cysteine endoprotease activity}

Soluble protein was isolated from each developmental stage by pounding $500 \mathrm{mg}$ of tissue in liquid nitrogen with presence of $2 \mathrm{~g}$ PVP in $3 \mathrm{~mL}$ buffer containing $50 \mathrm{mM}$ HEPES, $1 \mathrm{mM}$ DTT, $1 \mathrm{mM}$ EDTA, $1 \mathrm{mM} \mathrm{KOH} \mathrm{(pH} \mathrm{7.5).}$ Next the homogenate was centrifuged at $4{ }^{\circ} \mathrm{C}, 14,000 \mathrm{rpm}$ for $25 \mathrm{~min}$. The supernatant was fractioned into $5 \mathrm{ml}$ tubes. Soluble protein content was determined by Bradfod method (1976) at $595 \mathrm{~nm}$.

Total proteolytic activity and total cysteine endoprotease activity were measured as described by Zagdańska and Wiśniewski (1996). Enzymes were extracted in HEPES with $1 \mathrm{mM}$ DTT and $1 \mathrm{mM}$ EDTA, pH 7.5. To estimate total proteolytic activity, isolated extract was 
Fig. 1 Developmental phases of common lilac,

a inflorescence bud swelling,

b inflorescence elongation,

c flower bud whitening, $\mathbf{d}$ flower

bud swelling, e open flower,

f wilting

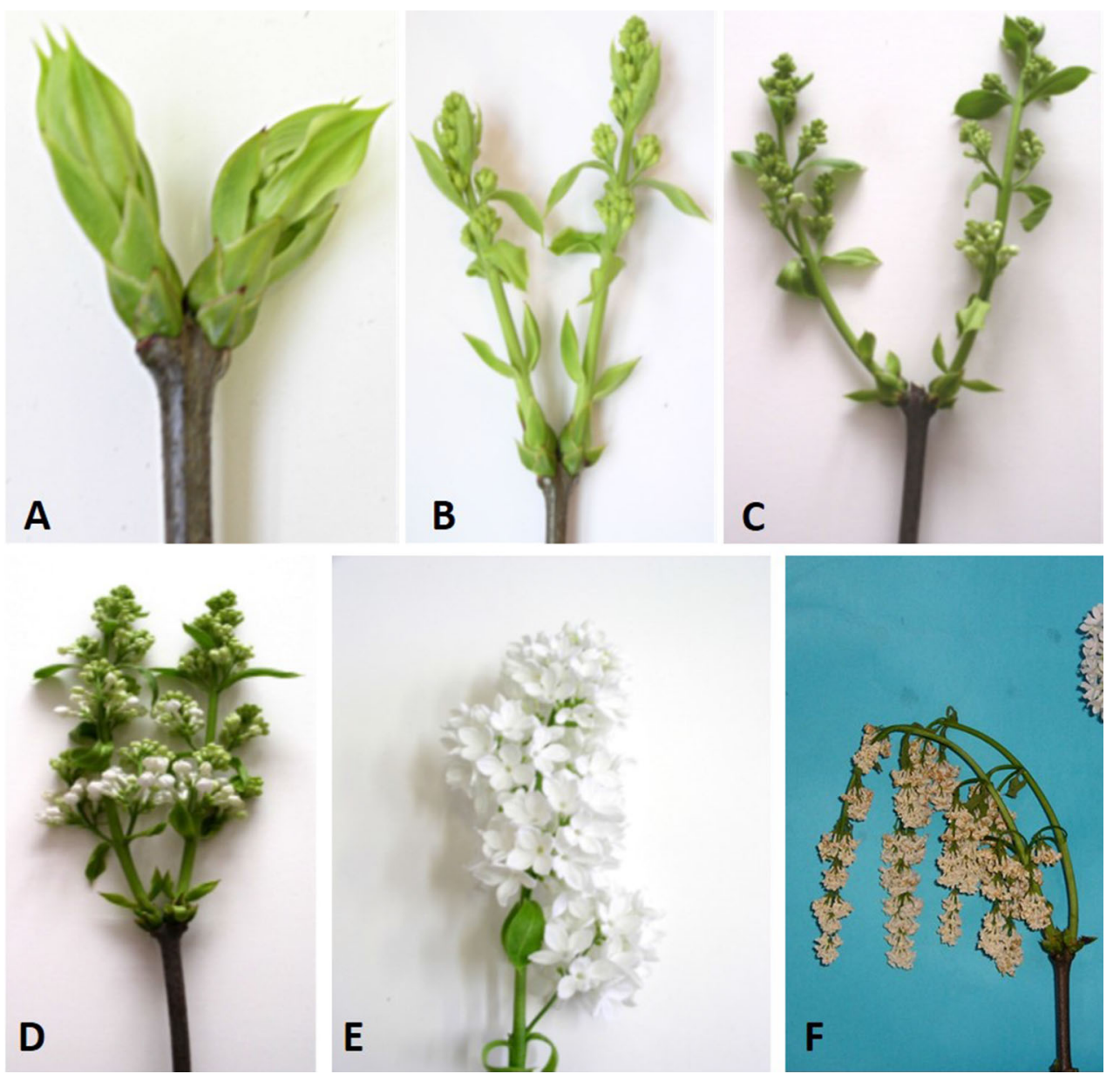

incubated for $3 \mathrm{~h}$ at $37{ }^{\circ} \mathrm{C}$ in a citrate-phosphate buffer $\mathrm{pH}$ 5.0 and azocaseine. To estimate cysteine endoprotease activity, $10 \mathrm{mM}$ iodoacetate was added to the isolated mixture, with azocaseine added after $1 \mathrm{~h}$ of incubation. The reaction was arrested by $24 \%$ TCA. The extinction was determined at $340 \mathrm{~nm}$. Obtained results were calculated in units per milligram protein in the sample (Bradford 1976), where 1 unit corresponds to an absorbance change at $340 \mathrm{~nm}$ of 0.01 per hour. All results were statistically evaluated with ANOVA 2. The means were compared by Duncan's test at a probability level of 0.95 .

\section{Isolation of a partial KDEL-CysEP encoding cDNA sequence}

Genes encoding KDEL-CysEPs were selected from the National Centre of Biotechnology Information. Universal primers were constructed from the most conserved regions of these sequences with the Primer 3 program. Total RNA samples were isolated using the Isolate II RNA Plant Kit (Bioline) according to the manufacturer's protocol. cDNA synthesis was performed with primers of Oligo DT using the Tetro cDNA Synthesis Kit (Bioline) with $1 \mu \mathrm{g}$ of total
RNA. $2 \mu \mathrm{L}$ of cDNA was used as template for PCR amplification using 2xPCR Maser Mix (Thermo Scientific) and primers universal to the six cysteine endoprotease genes. As a control, actin was amplified. Actin primers were designed to Olea europea act1 mRNA (GenBank accession no. AF545569.1) and included F GAATTGCCAGATGGACAGGT and R GAACCACCACTGAGGACGAT. The PCR steps were $94{ }^{\circ} \mathrm{C}$ for 3 min followed by 35 cycles of $94{ }^{\circ} \mathrm{C}$ for $30 \mathrm{~s}, 60{ }^{\circ} \mathrm{C}$ for $30 \mathrm{~s}, 72{ }^{\circ} \mathrm{C}$ for $1 \mathrm{~min}$, and final extension $72{ }^{\circ} \mathrm{C}$ for $10 \mathrm{~min}$ using a Mastercycler gradient thermocycler (Eppendorf, Hamburg, Germany). PCR products were separated on $1.0 \%$ agarose gel stained with ethidium bromide. As a negative control, template without DNA was made.

\section{Differential screening}

PCR fragments were purified using the Invisorb ${ }^{\circledR}$ Fragment Cleanup (Invitek, Germany) and cloned into the pGEM-T Easy vector system (Promega, Mannheim, Germany). The transformation was carried out with electro-competent E. coli strain DH10B (Invitrogen, Karlsruhe, Germany). Isolation of plasmid DNA was performed by using the 
Gene Jet ${ }^{\text {TM }}$ Plasmid Miniprep Kit (Fermentas) according to producer's instructions. The amplicons were sequenced with six independent replication using the Eurofins MWG Operon (Ebersberg, Germany). Sequence alignment and probability of sequence identities were led with CLUSTALW2 software (Thompson et al. 1997). Database searches were carried out with the Basic Logic Alignment Search Tool (BLAST) algorithm (Altschul et al. 1997). One sequence encoded a partial KDEL-CysEP. It was encoded in a 442 bp amplicon that was obtained with the following primers from the set of universal primers: $\mathrm{F} 5^{\prime} \mathrm{A}$ AACCAAGGATGCAATGGAG3', R 5'ACCACACAACC CCTCTTCAG3'.

\section{qRT-PCR}

Total RNA was prepared using the Isolate II RNA Plant Kit (Bioline). Synthesis of cDNA was carried out with primers of Oligo DT using the Tetro cDNA Synthesis Kit (Bioline). From the partial coding sequence of the Syringa KDELCysEP, the following primers, giving a product of $103 \mathrm{bp}$, were made for qRT-PCR: F 5'CAATGTCTCGCTGCAT CCTA3',

R 5'GGCTATGGCACAACACTTGA3'. The qRTPCR reactions were performed using the Pico Real 2.2 thermocycler (Thermo Scientific) and SensiFAST ${ }^{\mathrm{TM}}$ SYBR $^{\circledR}$ No-ROX Kit (Bioline). To guarantee that quantification of the achieved product could be considered as semiquantitative, reaction cycles were optimized for each primer set and each cDNA synthesis combination. Several dilution series of cDNA were involved in every PCR run, and results were only accepted when a linear response was acquired. Obtained data were analyzed using the $\Delta \Delta C_{\mathrm{t}}$ method (Livak and Schmittgen 2001) and presented as a level of gene expression relative to the reference gene $\beta$-actin (GenBank accession no. AF545569.1).

All analyses were done in plant material sampled in two consecutive years (2012 and 2013). As the results from these 2 years did not differ significantly, they were pooled and average values are presented.

\section{Results}

\section{Flower longevity}

The complete flowering cycle, from inflorescence bud swelling phase until flower wilting (loss of decorativity), lasted for 27 days in shrubs blooming naturally, 19 days in shrubs forced by the standard procedure $\left(37^{\circ} \mathrm{C}\right)$ in November and 49 days in shrubs forced in November by low temperature $\left(15^{\circ} \mathrm{C}\right)$ (Table 1$)$. The longest phase during the low-temperature forcing was the inflorescence bud swelling phase (A) which lasted for 16 days, during standard high temperature forcing this phase lasted only for 5 days and during natural blooming it lasted for 7 days. The inflorescence elongation phase (B) was the longest during natural blooming, where it lasted for 7 days, while during standard and alternative forcing it lasted for 3 and 6 days, respectively. Between the flower bud whitening phase $(C)$ and the open flower phase $(E)$, the dynamics of flower development was the same in both forcing treatments, and lasted for 2 to 4 days under natural conditions. The open flower phase was the longest following alternative forcing-17 days, while in the naturally blooming shrubs 8 days and during standard forcing only for 2 days.

\section{Soluble protein content and total protease activity}

Four different phases of flower development and senescence (developmental phases $\mathrm{C}-\mathrm{F}$ ) from three different treatments (natural growth in the field, November standard forcing under $37^{\circ} \mathrm{C}$, November alternative forcing under $15^{\circ} \mathrm{C}$ ), were selected for analyses of the total soluble protein content and proteolytic activity (Figs. 2, 3). In flowers collected from shrubs blooming naturally outdoors in May, the soluble protein content in phases C and D was about $55 \mathrm{mg}\left(\mathrm{g} \mathrm{FW}^{-1}\right.$, while in phase $\mathrm{E}$ it dropped to about $39 \mathrm{mg}$ (g FW) ${ }^{-1}$ (Fig. 2). During November forcing under standard conditions, the soluble protein content in flowers did not vary significantly and was $60-65 \mathrm{mg}\left(\mathrm{g} \mathrm{FW}^{-1}\right.$. During the alternative November forcing $\left(15^{\circ} \mathrm{C}\right)$, the protein content was generally higher
Table 1 Length of developmental phases (days) in lilacs forced under different conditions

\begin{tabular}{llll}
\hline Developmental phase & \multicolumn{2}{l}{ Day of developmental phase begins } \\
\cline { 2 - 4 } & $\begin{array}{l}\text { Natural } \\
\text { (May) }\end{array}$ & $\begin{array}{l}\text { November standard } \\
\text { forcing }\left(37^{\circ} \mathrm{C}\right)\end{array}$ & $\begin{array}{l}\text { November alternative } \\
\text { forcing }\left(15^{\circ} \mathrm{C}\right)\end{array}$ \\
\hline (A) Inflorescence bud swelling & 5 & 7 & 16 \\
(B) Inflorescence elongation & 12 & 10 & 22 \\
(C) Flower bud whitening & 14 & 13 & 28 \\
(D) Flower bud swelling & 15 & 15 & 30 \\
(E) Flowering & 19 & 17 & 32 \\
(F) Decorativity loss & 27 & 19 & 49
\end{tabular}


Fig. 2 Soluble protein content in flower buds and flowers of common lilac blooming in May, during November standard forcing $\left(37^{\circ} \mathrm{C}\right)$, and during November alternative forcing $\left(15^{\circ} \mathrm{C}\right)$. The following phases were studied (cf. Fig. 1):

(C) flower bud whitening,

(D) flower bud swelling,

(E) open flower, (F) wilting.

Means labeled with the same letter do not differ significantly at $P=0.05$. Data are representative of three different experiments
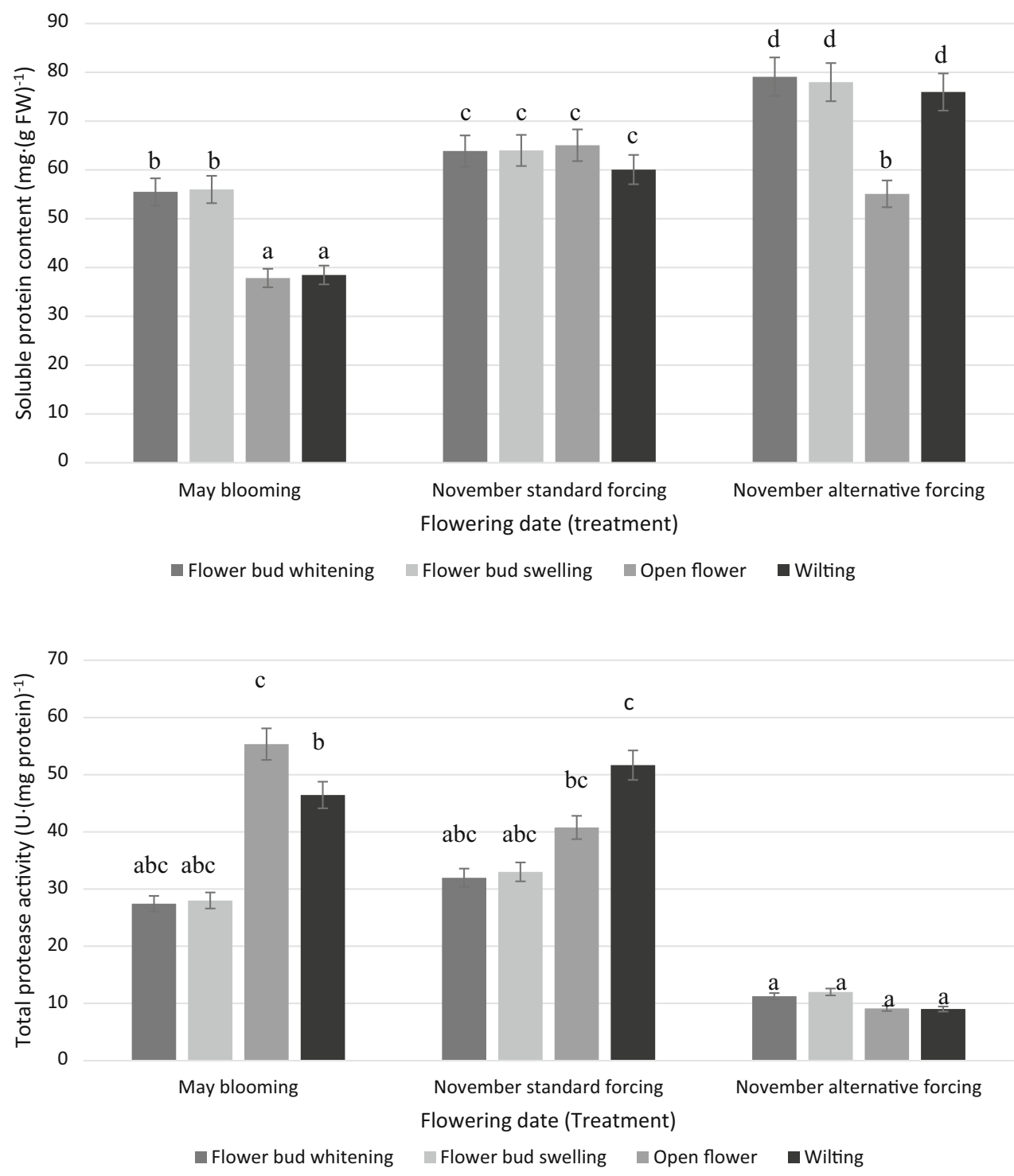

Fig. 3 Total protease activity in flower buds and flowers of common lilac blooming in May, during November standard forcing $\left(37^{\circ} \mathrm{C}\right)$, and during November alternative forcing $\left(15^{\circ} \mathrm{C}\right)$. The following phases were studied (cf. Fig. 1):

(C) flower bud whitening,

(D) flower bud swelling,

(E) open flower, (F) wilting.

Means labeled with the same letter do not differ significantly at $P=0.05$. Data are

representative of three different experiments
[60-65 $\mathrm{mg}\left(\mathrm{g} \mathrm{FW}^{-1}\right]$ than in any other treatment except that some reduction was observed in phase $\mathrm{E}$ (Fig. 2).

Total proteolytic activity varied depending on the treatment and the developmental phase. In shrubs blooming naturally in the field, the lowest activity of protease was in the phase of flower bud whitening/swelling and it doubled in the open flower phase to a value of $55 \mathrm{U}$ (mg protein) ${ }^{-1}$ (Fig. 3). During November forcing under standard conditions $\left(37^{\circ} \mathrm{C}\right)$, protease activity rose steadily from $32 \mathrm{U}$ (mg protein $)^{-1}$ in the phase of flower bud whitening/ swelling up to $52 \mathrm{U}$ (mg protein) $)^{-1}$ in the phase of wilting (Fig. 3). During alternative November forcing at $15^{\circ} \mathrm{C}$, protease activity was low in all the developmental phases and ranged between 9 and $11 \mathrm{U}$ (mg protein $)^{-1}$. Generally, the highest proteolytic activity was detected in the open flower phase in shrubs blooming naturally in the field and in the wilting phase after November standard forcing at $37{ }^{\circ} \mathrm{C}$ (Fig. 3).

The total activity of cysteine endoprotease was lower than the total protease activity (Fig. 4). In flower buds and flowers collected from shrubs blooming naturally in the field, the highest activity of cysteine endoprotease was observed in phase $\mathrm{E}\left[19 \mathrm{U}(\mathrm{mg} \text { protein })^{-1}\right.$ ], while it was nearly zero in the other developmental phases. During November standard forcing at $37{ }^{\circ} \mathrm{C}$, the cysteine endoprotease activity ranged between 28 and $39 \mathrm{U}$ (mg protein $)^{-1}$. A critical reduction of protease activity was observed in phase $F\left[15 \mathrm{U}(\mathrm{mg} \text { protein })^{-1}\right]$. During November alternative forcing at $15^{\circ} \mathrm{C}$, the cysteine endoprotease was low in all developmental phases, ranging between 6 and $9 \mathrm{U}(\mathrm{mg} \text { protein })^{-1}$. In conclusion, the highest activity of cysteine endoprotease was observed in 
Fig. 4 Total cysteine endoprotease activity in flower buds and flowers of common lilac blooming in May, during November standard forcing $\left(37^{\circ} \mathrm{C}\right)$, and during November alternative forcing $\left(15^{\circ} \mathrm{C}\right)$. The following phases were studied (cf. Fig. 1): (C) flower bud whitening, (D) flower bud swelling, (E) open flower, (F) wilting. Means labeled with the same letter do not differ significantly at $P=0.05$. Data are representative of three different experiments

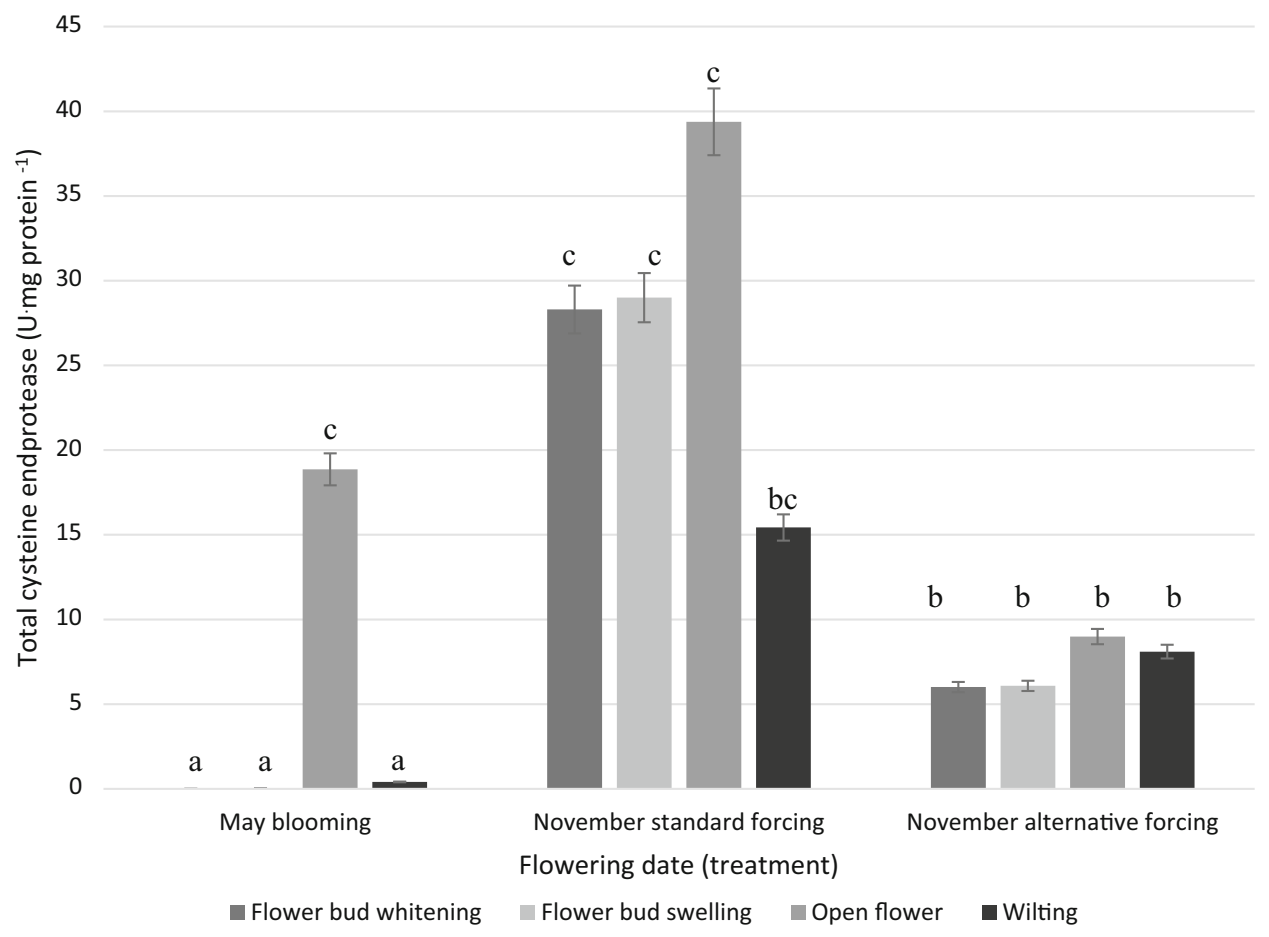

Table 2 Percent identity of the partial Syringa vulgaris CysP amino acid sequence to one KDEL and nine non-KDEL Petunia hybrida CysPs, to three KDEL and one non-KDEL Arabidopsis thaliana CysPs, and to KDEL CysPs from six other species

\begin{tabular}{llll}
\hline KDEL Cys proteases & \% Identity & Non-KDEL Cys proteases & \% Identity \\
\hline Petunia hybrida CP6 AY662992 & 98 & Arabidopsis thaliana SAG12 AAC49135 & 58 \\
Nicotiana tabacum CP2 AY881010 & 90 & Petunia hybrida CP10 AY662996 & 57 \\
Ricinus communis CP XM_002511790 & 81 & Petunia hybrida CP1 (P21) U31094 & 35 \\
Helianthus annuus CP2 AB109187 & 80 & Petunia hybrida CP3 AY662989 & 33 \\
Phaseolus vulgaris EP-C1 CAA40073 & 78 & Petunia hybrida CP5 AY662991 & 33 \\
Arabidopsis thaliana CEP1 AEE86713 & 77 & Petunia hybrida CP7 AY662993 & 26 \\
Iris hollandica CP AY504967 & 73 & Petunia hybrida CP9 AY662995 & 22 \\
Arabidopsis thaliana CEP2 AEE78403 & 71 & Petunia hybrida CP4 AY662990 & 20 \\
Arabidopsis thaliana CEP3 AEE78406 & 67 & Petunia hybrida CP2 AY662988 & 19 \\
Hemerocallis hybrida SEN11 U12637 & 65 & Petunia hybrida CP8 AY662994 & 1.4 \\
\hline
\end{tabular}

flowers collected from shrubs forced in November by standard procedure, at $37^{\circ} \mathrm{C}$.

\section{Isolation and characterization of KDEL-CysEP cDNA}

Partial and complete KDELCysEP cDNA sequences available in databases were used to design primers for isolation of KDEL-CysEP and transcript quantification at different developmental phases. Only one primer pair ( $\mathrm{F}$ 5'AAACCAAGGATGCAATGGAG3' and R 5'ACCACA CAACCCCTCTTCAG3') gave a clear product of $442 \mathrm{bp}$. Sequencing and comparison to database sequences confirmed the identity of obtained cDNA. The homology of the encoded 147 amino acid protein sequence to ten KDELCysEPs and ten non-KDEL-CysEPs are shown in Table 2. The nucleotide and encoded amino acid sequence of the isolated common lilac cDNA both showed $98 \%$ identity to the sequences for PhCP6, a KDEL-CysEP whose cDNA was isolated from Petunia hybrida petals (Figs. 5, 6; Table 2). The PhCP6 protein sequence was the sequence most closely related to the Syringa protein sequence found in the available databases. Table 2 shows identities of the Syringa protein sequence to $10 \mathrm{KDEL}$ and 10 non-KDEL protein sequences. The identities to the KDEL-CysEPs in the Table are between 65 (Hemerocallis SEN11) and $98 \%$ (Petunia CP6), and the identities to the non-KDEL-CysEPs are between 1.4 (Petunia CP8) and $59 \%$ (Arabidopsis 
S.vulgaris:AAACCAAGGATGCAATGGAGGGTTGATGGATTTGGCATTTGACTTCATCAAGAAGAAGGGAGGCATCACTACAGAGGAGA 80

P.hybrida: AAACCAAGGATGCAATGGAGGGTTGATGGATTTGGCATTTGACTTCATCAAGAAGAAGGGAGGTATCACTACAGAGGAGA

S.vulgaris: ACTATCCTTACATGGCTGTAGATGGCAAGTGTGACCTTCAAAAGAGGTATACTCCCGTTGTATCAATTGACGGACATGAG 160

P.hybrida: ACTATCCTTACATGGCTGCAGATGGCAAGTGTGACCTTAAAAAGAGGAATACTCCCGTTGTATCCATTGACGGACATGAG

S.vulgaris: GATGTTCCTCCAAATGATGAGGAATCACTCCTTAAAGCAGTAGCCAACCAGCCGGTTTCCGTAGCCATAGAAGCTTCAGG 240

P.hybrida: GATGTTCCTCCTAATGATGAGGAATCACTCCTTAAAGCAGTAGCCAACCAGCCTGTTTCCGTAGCCATAGAAGCTTCAGG

S.vulgaris: TTCTGATTTCCAGTTCTACTCTGAGGGTGTATTCACTGGAGATTGTGGTACTGAGTTGGACCATGGGGTGGCAATTGTAG 320

P.hybrida: TTCTGATTCCAGTTCTACTCTGAGGGTGTATTCACTGGAGATTGTGGTACTGAGTTGGACCATGGGGTGGCAATTGTAG

S.vulgaris: GCTATGGCACAACACTTGATGGAACCAAATACTGGACTGTGAGGAACTCATGGGGACCTGAATGGGGAGAAAAAGGATAC 400

P.hybrida: GCTATGGCACAACACTTGATGGAACCAAATACTGGACAGTGAGGAACTCATGGGGACCTGAATGGGGAGAAAAAGGATAC

S.vulgaris: ATTAGGATGCAGCGAGACATTGATGCTGAAGAGGGGTTGTGT 442

P.hybrida: ATTAGGATGCAGCGAGACATTGACGCTGAAGAGGGGTTGTGT

Fig. 5 Alignment by the Clustal W program of the 442 nucleotide coding strand from the partial Syringa vulgaris KDEL-CysEP cDNA and the corresponding sequence of Petunia hybrida CP6 cDNA sequence (AY662992). There are nine differences between the two
DNA sequences (indicated in red). Between the corresponding encoded 147 amino acid sequences there are only three differences (cf. Fig. 6) due to codon changes resulting from the three underlined base substitutions
Syringa vulgaris Helianthus annuus Hemerocallis hybrida Iris hollandica Nicotiana tabacum Petunia hybrida Ricinus communis

Syringa vulgaris Helianthus annuus Hemerocallis hybrida Iris hollandica Nicotiana tabacum Petunia hybrida Ricinus communis

Syringa vulgaris Helianthus annuus Hemerocallis hybrida Iris hollandica Nicotiana tabacum Petunia hybrida Ricinus communis
NQGCNGGLMDLAFDF IKKKGGITTEENY PYMAVDDGKCDLQKRYYTPVVS I DGHEDVP PNDEES LLKAVANQ NQGCNGGLMDLAFDFIKKTGGLTREDAYPYAAEDGKCDSNKMNS PVVS I DGHEDVPKNDEQS LMKAVANQ a NSGCNGGLMDYAFDFIKNNGGLSSEDSYPYLAEQKSCG-SEANSAVVTIDGYQDVPRNNEAALMKAVANQ NEGCNGGLMDYAFEFIKSNGGITSESAYPYTAEQGSCA-SESSAPVVTIDGYEDVPANNEAALMKAVANQ NQGCNGGLMDMAFEFIKKKGGINTEENYPYMAEGGECDIQKRNSPVVS I DGYEDVPPNDEDS LLKAVANQ NQGCNGGLMDLAF DF I KKKGGITTEENY PYMA A D GKCDLKKRNT PVVS I DGHEDVP PNDEE S LLKAVANQ NQGCNGGLMDYAFEFIKQRGGITTEANYPYEAYDGTCDVSKENAPAVS I DGHENVPENDENALLKAVANQ PVSVAIEASGSDFQFYSEGVFTGDCGTELDHGVAIVGYGTTLDGTKYWTVRNSWGPEWGEKGYIRMQRDI 140 PVAVAIDAGSSDFQFYSEGVFTGKCGTQLDHGVAAVGYGTTLDGTKYWIVRNSWGSEWGEKGYIRMERGI PVSVAIEASGYAFQFYSQGVFSGHCGTELDHGVAAVGYGVDDDGKKYWIVKNSWGEGWGESGY IRMERGI VVSVAIEASGMAFQFYSEGVFTGSCGNELDHGVAVVGYGATRDGTKYWIVRNSWGAEWGEKGY IRMQRGI PVSVAIQASGSDFOFYSEGVFTGDCGTELDHGVAIVGYGTTLDGTKYWIVRNSWGPEWGEKGYIRMQREI PVSVAIEASGSDFQFYSEGVFTGDCGTELDHGVAIVGYGTTLDGTKYWTVRNSWGPEWGEKGYIRMQRDI PVSVAIDAGGSDFOFYSEGVFTGSCGTELDHGVAIVGYGTTIDGTKYWTVKNSWGPEWGEKGYIRMERGI

DAEEGLC 147 SDKRGLCGIAMEASYPIKNSSNNPKSSPTSSLKDEI KDKRGKCGIAMEASYPIK-SSPNPKK--AESLKDEL RARHGLCGIAMEPSYPLK-TSPNPKN--NISPKDEL DAEEGLCGIAMQPSYPIKTSSSNPTGSPATAPKDEL DAEEGLCGIAMQPSYPIKTSSDNPTGTPAATPKDEL SDKEGLCGIAMEASYPIKKSSNNPSG-IKSSPKDEL
Fig. 6 Alignment by the Clustal W program of the 147 amino acid partial sequence of Syringa vularis KDEL-CysEP to the carboxyterminal sequences (172-176 amino acids) of the following KDELCysEPs: Helianthus annuus CP2 (AB109187), Hemerocallis hybrida SEN11 (U12637), Iris hollandica CP (AY504967), Nicotiana

SAG12). Thus, it can be concluded that the Syringa protein belongs to the KDEL-CysEP group, although the C-terminal part of the protein sequence was not determined. An alignment of the Syringa protein with 6 of the KDELCysEPs from Table 2 is shown in Fig. 6.

\section{Expression of the KDEL-CysEP protease during flower development and senescence}

To investigate the expression pattern of the Syringa KDELCysEP during flower development and senescence under tabacum CP2 (AY881010), Petunia hybrida CP6 (AY662992), and Ricinus communis CP (XM_002511231). Amino acids that are identical in all shown sequences are indicated in red. The Syringa and Petunia sequences deviate in three amino acid residues (underlined)

different conditions, quantitative RT-PCR was used. In flowers collected from shrubs blooming under natural conditions, the transcript abundance at phase $\mathrm{E}$ increased 2.5 -fold to $1400 \mathrm{U}$ (units of transcript relative to $\beta$-actin transcript) relative to phases $\mathrm{C}$ and $\mathrm{D}$ (Fig. 7). At phase $\mathrm{F}$, the expression was still high, viz. $1180 \mathrm{U}$, which is higher than that for the two sets of forcing conditions (Fig. 7). In flowers collected from shrubs forced in November at $37{ }^{\circ} \mathrm{C}$, the relative expression increased sixfold-to $1970 \mathrm{U}$-from phase $\mathrm{C}$ to phase $\mathrm{E}$. For flowers forced at $15^{\circ} \mathrm{C}$, the highest relative expression-2300 U-was in 
Fig. 7 Expression of KDELCysEP gene (relative to $\beta$ actin gene) in flower buds and flowers of common lilac blooming in May, during November standard forcing $\left(37^{\circ} \mathrm{C}\right)$, and during November alternative forcing $\left(15^{\circ} \mathrm{C}\right)$. The following phases were studied (cf. Fig. 1):

(C) flower bud whitening,

(D) flower bud swelling,

(E) open flower, (F) wilting. Means labeled with the same letter do not differ significantly at $P=0.05$. Data are representative of three different experiments

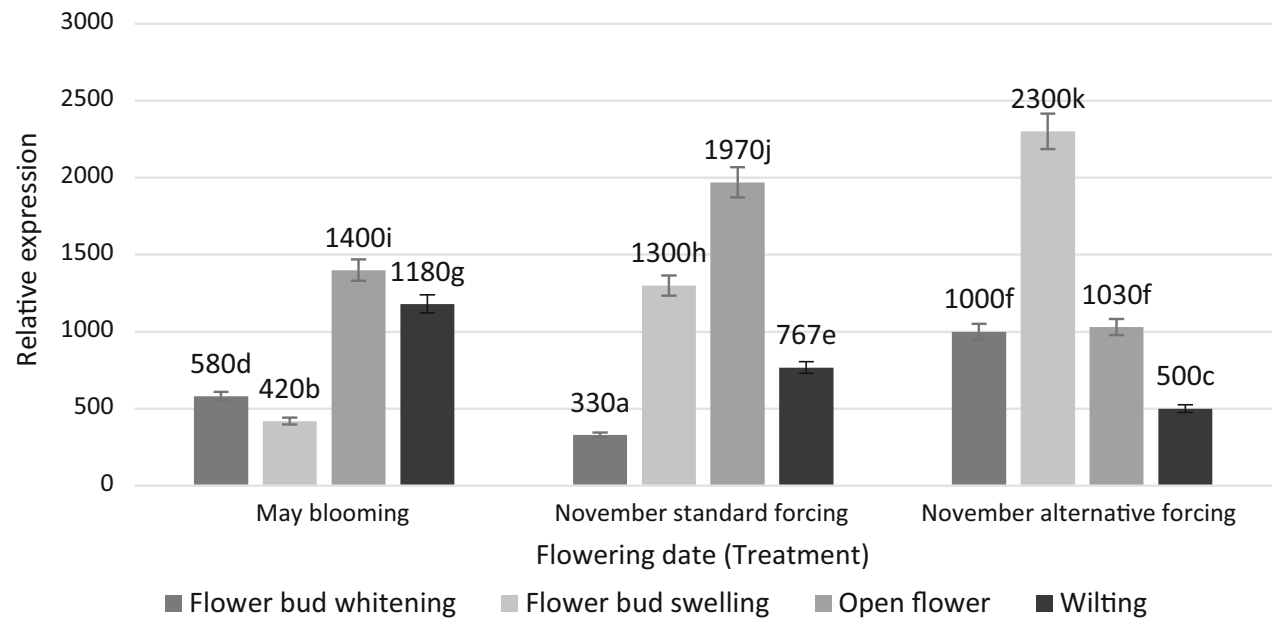

phase D (Fig. 7). At the phase of open flower, the expression had decreased twofold and at phase $\mathrm{F}$ fourfold relative to the flower bud swelling phase (Fig. 7).

\section{Discussion}

The most characteristic feature of programmed cell death during organ senescence is the protein degradation (Huffaker 1990). Petal senescence is usually connected to decreased protein level, increased proteolytic activity, and up-regulation of cysteine protease genes (Jones et al. 2005 according to Jones 2004). In most of the examined plant organs, the protein contents keep decreasing non-committally with senescence (Wagstaff et al. 2002). Protein breakdown as a part of the remobilization process during flower senescence, has been extensively noted in several different species (Battelli et al. 2011). In naturally blooming lilacs, the soluble protein content remained low in all developmental phases as compared to lilacs blooming as a consequence of forcing (Fig. 2). The highest soluble protein content was observed in flower buds and flowers (phase C and D) collected from shrubs alternatively forced in November at $15{ }^{\circ} \mathrm{C}$. The protein content dropped in the open flower (phase E) and then increased again in the wilting phase (phase F), presumably as a consequence of an extensive water loss. In neither treatment did we notice a dramatic drop of the total protein content as it was observed in other ornamentals (Stephenson and Rubinstein 1998; Wagstaff et al. 2002; Arora and Singh 2004; Battelli et al. 2011; Mochizuki-Kawai et al. 2013). An exception was Alstroemeria, which showed only traces of protein loss and slight change in fresh weight, although such classical signs of senescence such as petal inrolling and color change were evident (Wagstaff et al. 2002).

In flowers collected from shrubs blooming naturally, the total protease activity rose sharply from phase $\mathrm{D}$ to $\mathrm{E}$ and then dropped somewhat in the last phase (F) (Fig. 3). In flowers collected from shrubs forced in November by standard method, under $37^{\circ} \mathrm{C}$, the total protease activity increased steadily from phase $\mathrm{C}$ to $\mathrm{F}$, while during November alternative forcing at $15{ }^{\circ} \mathrm{C}$, the total protease activity was approximately constant in all phases and very low compared to the other treatments. When comparing the results of the total protease activity and the soluble protein content for all phases of all three treatments, it is obvious that the protein content is inversely related to the total protease activity (Figs. 2, 3).

The highest soluble protein content and the lowest proteolytic activity were observed in flowers from shrubs forced at low temperature. At the same time, the panicles under these conditions required the longest forcing period and remained in the phase of open flowers for 17 days as compared to barely 2 days in shrubs forced under high temperature (Table 1). Thus, $15^{\circ} \mathrm{C}$ during the entire forcing period effectively delays senescence in lilac flowers.

The highest total cysteine protease activity was for all phases detected in flowers collected from shrubs forced under standard conditions while the activity in flowers from control shrubs and those forced alternatively, under $15^{\circ} \mathrm{C}$ was considerably lower (Fig. 4). This difference is evidently due to the physiological conditions of forced plants. The standard forcing procedure requires temperatures close to heat shock, which facilitates the break of the deep dormancy state, but also upregulates cysteine protease activity (Fig. 4) and shortens flower life (Table 1). Cytological observation of flower development and senescence in forced lilacs provided evidence that the first symptoms of petal degradation had already started in the flower bud (Jędrzejuk et al. 2013), while degradation of reproductive structures was already evident in inflorescence elongation phase (Jędrzejuk 2005; Jedrzejuk and Lukaszewska 2008a, b). These observations and the expression pattern of 
cysteine endoprotease activity shown in Fig. 4 may suggest that cysteine endoproteases have important roles in PCD.

To elucidate the role of cysteine endoproteases during flower senescence, genes of cysteine protease that up-regulate during flower senescence, have been cloned from the petals of Dianthus caryophyllus (Jones et al. 1995), Hemerocallis (Valpuesta et al. 1995; Guerrero et al. 1998), Alstroemeria peruviana (Wagstaff et al. 2002), Sandersonia aurantiaca (Eason et al. 2002), Narcissus pseudonarcissus (Hunter et al. 2007), and Gladiolus grandiflora (Arora and Singh 2004). It has been found that many of the senescence associated cysteine proteases are KDELCysEPs (Helm et al. 2008; Höwing et al. 2014). KDELCysEPs belong to an important group of cysteine endoproteases that are unique to plants by a characteristic C-terminal KDEL sequence directing retention in the endoplasmic reticulum (ER) (Helm et al. 2008; Höwing et al. 2014; Battelli et al. 2014). These proteases were identified in senescing cell of castor bean (Ricinus communis) endosperm (Schmid et al. 1994), cotyledons of Vicia sativa (Becker et al. 1997), the maturing pods of Phaseolus vulgaris (Tanaka et al. 1991), the unpollinated ovaries of Pisum sativum (Cercos et al. 1999), and in developing integument of the seed coat of Phalaenopsis (Nadeau et al. 1996) as well as found in senescing petals of several species such as Hemerocallis hybrida, Sandersonia aurantiaca, Dendrobium (Lerslerwong et al. 2009; Valpuesta et al. 1995; Eason et al. 2002).

No cysteine endoprotease sequence from common lilac was previously known. In the present work, we decided to clone a partial sequence of a KDEL-CysEP cDNA in lilac, to compare its expression during flower development under different blooming conditions and in relation to the species mentioned above. The isolated partial cDNA showed $98 \%$ identity at both the DNA and protein level to Petunia hybrida CP6, which is a KDEL-CysEP expressed in petals (Jones et al. 2005) and $65 \%$ to Hemerocallis hybrida SEN11. The Syringa protein sequence was $90 \%$ identical to Nicotiana tabacum $\mathrm{CP} 2$ expressed in Nicotiana tabacum leaves (Beyene et al. 2006). The Syringa protein is compared to $10 \mathrm{KDEL}-\mathrm{CysEPs}$ and 10 non-KDEL-CysEPs in Table 2. Identity to KDEL enzymes are between 65 (Hemerocallis) and $98 \%$ (Petunia). Identity to non-KDEL enzymes are between 1.4 (Petunia CP8) and $59 \%$ (Arabidopsis SAG12). It is concluded that the Syringa sequence is a KDEL-CysEP very closely related to the Petunia hybrida CP6 protein. On the other hand, PhCP6 isolated from Petunia petals, shows a high homology to CysEP from castor bean and also other KDEL-containing cysteine proteases (Hierl et al. 2012 according to: Jones et al. 2005). According to Hierl et al. (2012), KDEL-CysEPs form a separate subgroup (C1A-2) among the papain-like cysteine proteases (C1A family). According to Beyene et al.
(2006) the expression profiles of this group, are rather variable between species, that could be an explanation for such a close phylogenetic relationship between CP6 and KDEL-CysEP in S. vulgaris.

The expression of the KDEL-CysEP (Fig. 7) and the total cysteine endoprotease activity (Fig. 4) in common lilac blooming naturally or during standard forcing in November at $37{ }^{\circ} \mathrm{C}$, were maximal in phase $\mathrm{E}$ (open flower phase). In lilacs flowering naturally in May, the expression pattern of KDEL-CysEP was very similar to the pattern of total protease activity. The expression of KDEL-CysEP in lilacs forced in November under standard temperature $37{ }^{\circ} \mathrm{C}$, coincided with total cysteine endoprotease activity. The highest diversity between total endoprotease activity, total cysteine endoprotease activity, and KDEL-CysEP expression, was observed in flowers collected from alternative forcing $\left(15^{\circ} \mathrm{C}\right)$. In this treatment endoprotease activity remained at low level, while the expression of KDEL-CysEP reached the maximum in flower bud swelling phase. This diversity may result in a different accumulation of KDEL-CysEP and other cysteine endoproteases. KDEL-CysEP are commonly localized in the tissues undergoing PCD (Hierl et al. 2012), i.e., ricinosomes formed at the beginning of programmed cell death and found in an endospoerm of a castor bean (Hierl et al. 2012; Battelli et al. 2014).

In many plants, transcripts of cysteine endoproteases show comparatively low expression in petals as buds open but a clear increase in later phases of petal wilting (Wagstaff et al. 2002; Guerrero et al. 1998; Stephenson and Rubinstein 1998; Celikel and van Doorn 1995; Jones et al. 1995; Valpuesta et al. 1995 Smart 1994;). In common lilac, during May and November standard forcing $\left(37^{\circ} \mathrm{C}\right)$, the highest expression of the KDEL-CysEP was observed in an open flower phase, while during alternative November forcing $\left(15^{\circ} \mathrm{C}\right)$, the highest expression was noticed in flower bud swelling phase (Fig. 7). In all three treatments, the transcript expression was visibly decreased during flower wilting. In Petunia hybrida the highest expression of PhCP6 was observed in senescing corollas, while downregulation occurred in developing flowers (Jones et al. 2005). The KDEL-CysEP LICYP expressed in Lilium longiflorum tepals showed drastically low expression during bud opening. Its expression increased only, once flowers achieved maturity phase, until the tepals entered senescence (Battelli et al. 2014). Arabidopsis thaliana has three KDEL-CysEPs (CEP1, CEP2, and CEP3) that appear to contribute to PCD (Helm et al. 2008; Höwing et al. 2014), but their role in flower senescence is not characterized to our knowledge.

Studies of proteolytic processes provide important clues to the regulation of floral senescence. In common lilac, the total cysteine protease activity was significantly higher at 
all stages of flowering for shrubs forced in November at $37{ }^{\circ} \mathrm{C}$ than for naturally blooming shrubs or shrubs alternatively forced in November at $15^{\circ} \mathrm{C}$. The cysteine endoprotease activity in open flowers is, furthermore, significantly lower for shrubs alternatively forced in November at $15^{\circ} \mathrm{C}$. The expression of the identified KDELCysEP is less different for the three sets of conditions than the total proteolytic activity, so other cysteine endoproteases seem to be more affected by the blooming conditions. The results therefore show that even gentle stimulation of plants to bloom in its state of deep dormancy affects the expression of several cysteine endoproteases that eventually have an impact on quality of the final product, i.e., the flowers. Mild forcing at $15^{\circ} \mathrm{C}$ affects the flowering process by prolonging it up to 49 days and delaying senescence, presumably due to the low cysteine protease activity.

Author contribution statement Agata Jędrzejuk designed and carried out the experiments, provided the preparation of the study material, analyzed the results, and wrote the manuscript. Julita Rabiza-Świder conceived of research area. Ewa Skutnik supervised statistical analyses. Margrethe Serek contributed scientific advice, correction, and final revision of the manuscript.

Acknowledgments Experiments were partly carried out within the frames of the NCN (National Center of Knowledge) project NN310 089336. The authors would like to thank Prof. em. Bjarne M. Stummann (University of Copenhagen, Denmark) for his critical review of the manuscript and valuable advice.

Open Access This article is distributed under the terms of the Creative Commons Attribution 4.0 International License (http://crea tivecommons.org/licenses/by/4.0/), which permits unrestricted use, distribution, and reproduction in any medium, provided you give appropriate credit to the original author(s) and the source, provide a link to the Creative Commons license, and indicate if changes were made.

\section{References}

Altschul SF, Madden TL, Schäffer AA, Zhang J, Zhang Z, Miller W, Lipman DJ (1997) Gapped BLAST and PSI-BLAST: a new generation of protein database search programs. Nucleic Acids Res 25(17):3389-3402

Arora A, Singh VP (2004) Cysteine protease gene expression and proteolytic activity during floral development and senescence in ethylene-insensitive Gladiolus grandiflora. J Plant Biochem Biotechnol 13:123-126

Azeez A, Sane AP, Bhatnagar D, Nath P (2007) Enhanced expression of serine proteases during floral senescence in Gladiolus. Phytochemistry 68:1352-1357. doi:10.1016/j.phytochem.2007. 02.027

Battelli R, Lombardi L, Rogers HJ, Picciarelli P, Lorenzi R, Ceccarelli N (2011) Changes in ultrastructure, protease and caspase-like activities during flower senescence in Lilium longiflorum. Plant Sci 180:716-725. doi:10.1016/j.plantsci. 2011.01.024

Battelli R, Lombardi L, Picciarelli P, Lorenzi R, Frigerio L, Rogers HJ (2014) Expression and localisation of a senescence-associated KDEL-cysteine protease from Lilium longiflorum tepals. Plant Sci 214:38-46. doi:10.1016/j.plantsci.2013.09.011

Becker C, Senyuk VI, Shutov AD, Nong VH, Fischer J, Horstmann C, Müntz K (1997) Proteinase A, a storage globulin degrading endopeptidase of vetch (Vicia sativa L.) seeds, is not involved in early steps of storage protein mobilization. Eur $\mathrm{J}$ Biochem 248:304-312

Beyene G, Foyer CH, Kuner KJ (2006) Two new cysteine proteinases with specific expression patterns in mature and senescent tobacco (Nicotiana tabacum L.) leaves. J Exp Bot 57(6):1431-1443. doi:10.1093/jxb/erj123

Bieleski RL (1995) Onset of phloem export from senescent petals of daylily. Plant Physiol 109:557-565

Bradford M (1976) A rapid and sensitive method for the quantitation of microgram quantities of protein utilizing the principle of protein-dye binding. Anal Biochem 72:248-254

Brzin J, Kidrič M (1996) Proteinases and their inhibitors in plants: role in normal growth and in response to various stress conditions. Biotechnol Genet Eng Rev 13(1):421-468. doi:10. 1080/02648725.1996.10647936

Celikel FG, van Doorn WG (1995) Solute leakage, lipid peroxidation, and protein degradation during senescence of iris tepals. Physiol Plant 94:514-521

Cercos M, Santamaria S, Carbonell JSO (1999) Cloning and characterization of TPE4A, a thiol-protease gene induced during ovary senescence and seed germination in pea. Plant Physiol 119:1341-1348. doi:10.1104/pp.119.4.1341

Coupe SA, Sinclair BK, Watson LM, Heyes JA, Eason JR (2003) Identification of dehydration-responsive cysteine proteases during post-harvest senescence of broccoli florets. J Exp Bot 54:1045-1056

Dale A, Sample A, King E (1999) Breaking dormancy in red raspberries for greenhouse production. Hortic Sci 38(4):515-519

Eason JR, Ryan DJ, Pinkney TT, O’Donoghue EM (2002) Programmed cell death during flower senescence: isolation and characterization of cysteine proteinases from Sandersonia aurantiaca. Funct Plant Biol 29:1055-1064

Ellis RE, Yuan J, Horvitz HR (1991) Mechanisms and functions of cell-death. Ann. Rev. Cell Biol. 7:663-698

Guerrero C, de la Calle M, Reid MS, Valpuesta V (1998) Analysis of he expression of two thiolprotease genes from daylily (Hemerocallis spp.) during flower senescence. Plant Mol Biol 36:565-571

Helm M, Schmid M, Hierl G, Terneus K, Tan L, Lottspeich F, Kieliszewski MJ, Gietl C et al (2008) KDEL-tailed cysteine endopeptidases involved in programmed cell death, intercalation of new cells, and dismantling of extensin scaffold Am. J Bot 95:1049-1062

Hierl G, Vothknecht U, Gietl C (2012) Programmed cell death in Ricinus and Arabidopsis: the function of KDEL cysteine peptidases in development. Physiol Plant 145:103-113. doi:10. 1111/j.1399-3054.2012.01580.x

Höwing T, Huesmann C, Hoefle C, Nagel MK, Isono E, Hückelhoven R, Gietl C (2014) Endoplasmic reticulum KDEL-tailed cysteine endopeptidase 1 of Arabidopsis (AtCEP1) is involved in pathogen defense. Front Plant Sci 5(58):1-11. doi:10.3389/fpls. 2014.00058

Huffaker RC (1990) Proteolytic activity during senescence of plants. New Phytol 116:199-231

Hunter PR, Craddock CP, Di Benedetto S, Roberts LM, Frigerio L (2007) Fluorescent reporter proteins for the tonoplast and the 
vacuolar lumen identify asingle vacuolar compartment in Arabidopsis cells. Plant Physiol 145:1371-1382

Jędrzejuk A (2005) Ultrastructure of pollen grains from forced and unforced shrubs in common lilac. J Plant Growth Regul 24:1-10

Jędrzejuk A, Łukaszewska A (2008a) High temperatures applied at fall forcing disturb ovule development in Syringa vulgaris L. "Mme Florent Stepman". Acta Physiol Plant 30:673-678

Jędrzejuk A, Łukaszewska A (2008b) Winter forcing affects anther development in common lilac (Syringa vulgaris L.). Floricult Ornam Biotechnol 2(2):39-43

Jędrzejuk A, Łukaszewska A (2008c) Wpływ temperatury na fazy fenologiczne i jakość kwiatostanów lilaka podczas pędzenia listopadowego. Zeszyty Problemowe Postępów Nauk Rolniczych 525:189-195

Jędrzejuk A, Rochala J, Dolega M, Łukaszewska A (2013) Comparison of petal senescence in forced and unforced common lilac flowers during their postharvest life. Acta Physiol Plant 35:1785-1796. doi:10.1007/s11738-013-1216-y

Jones ML (2004) Changes in gene expression during senescence. In: Nooden L (ed) Plant cell death processes. Elsevier Science, San Diego, pp 51-72

Jones ML, Larsen PB, Woodson WR (1995) Ethylene-regulated expression of a carnation cysteine proteinase during flower petal senescence. Plant Mol Biol 28:505-512

Jones ML, Chaffin GS, Eason JR, Clark DG (2005) Ethylenesensitivity regulates proteolytic activity and cysteine protease gene expression in petunia corollas. J Exp Bot 56:2733-2744. doi:10.1093/jxb/eri266

Lerslerwong L, Ketsa S, van Doorn WG (2009) Protein degradation and peptidase activity during petal senescence in Dendrobium cv. Khao Sanan Postharv. Biol Technol 52:84-90

Livak KJ, Schmittgen TD (2001) Analysis of relative gene expression data using real-time quantitative PCR and the 22DDCT method. Methods 25:402-408. doi:10.1006/meth.2001.1262

Mochizuki-Kawai H, Shibuya K, Ichimura K (2013) Programmed cell death begins earlier in the mesophyll cells of tulip petals than in the epidermal cells. Postharvest Biol Technol 79:9-12. doi:10. 1016/j.postharvbio.2012.12.010

Nadeau JA, Zhang XS, Li J, O'Neill SD (1996) Ovule development: identification of stage specific and tissue specific cDNAs. Plant Cell 8:213-239. doi:10.1105/tpc.8.2.213

Panavas T, Bubinstein B (1998) Oxidative events during programmed cell death of daylily (Hemerocallis hybrida) petals. Plant Sci 133:125-138

Schmid M, Simpson D, Gietl C (1994) Programmed cell death in castor beanendosperm is associated with the accumulation and release of a cysteine endopeptidase from ricinosomes. PNAS 96:14159-14164

Smart C (1994) Gene expression during leaf senescence. New Phytol 126:419-448

Soudry E, Ulitzur S, Gepstein S (2005) Accumulation and remobilization of amino acids during senescence of detached and attached leaves: in planta analysis of tryptophan levels by recombinant luminescent bacteria. J Exp Bot 56:695-702

Stead AD, van Doorn WG (1994) Strategies of flower senescence a review. In: Scott RJ, Stead AD (eds) Molecular and cellular aspects of plant reproduction. Cambridge University Press, Cambridge, pp 215-238

Steller H (1995) Mechanisms and genes of cellular suicide. Science 267(5203):1445-1449. doi:10.1126/science.7878463

Stephenson P, Rubinstein B (1998) Characterization of proteolytic activity during senescence in day lilies. Physiol Plant 104:463-473

Tanaka T, Yamauchi D, Minamikawa T (1991) Nucleotide sequence of cDNA for an endopeptidase (EP-C1) from pods of maturing Phaseolu svulgaris fruits. Plant Mol Biol 16:1083-1084. doi:10. 1007/BF00016081

Thompson JD, Gibson TJ, Plewniak F, Jeanmougin F, Higgins DG (1997) The CLUSTAL_X windows interface: flexible strategies for multiple sequence alignment aided by quality analysis tools. Nucleic Acids Res 25(24):4876-4882

Valpuesta V, Lange NE, Guerrero C, Reid MS (1995) Upregulation of cysteine protease accompanies the ethylenein sensitive senescence of daylily (Hemerocallis) flowers. Plant Mol Biol 28:575-582

van Doorn WG, Woltering EJ (2008) Physiology and molecular biology of petal senescence. J Exp Bot 59(3):453-480

van Doorn WG, Balk PA, van Houwelingen AM, Hoeberichts FA, Hall RD, Vorst O, van der Schoot C, van Wordragen MF (2003) Gene expression during anthesis and senescence in Iris flowers. Plant Mol Biol 53:845-863

Wagstaff C, Leverentz MK, Griffiths G, Thomas B, Chanasut U, Stead AD, Rogers HJ (2002) Cysteine protease gene expression and proteolytic activity during senescence of Alstroemeria petals. J Exp Bot 53(357):233-240

Wagstaff C, Malcolm P, Rafiq A, Leverentz M, Griffiths G, Thomas B, Stead A, Rogers H (2003) Programmed Cell Death (PCD) processes begin extremely early in Alstroemeria petal senescence. New Phytol 160:49-59

Zagdańska B, Wiśniewski K (1996) Endoproteinase activities in wheat leaves upon water deficits. Acta Biochem Pol 43:512-520 